\title{
SAFRAN-Grocus snow simulations in an unstable and windy climate
}

\author{
Svanbjörg Helga Haraldsdóttir, ${ }^{1}$ Haraldur Ólafsson, ${ }^{2}$ Yves Durand, ${ }^{3}$ \\ Laurent Mérindol, ${ }^{3}$ Gérald Giraud ${ }^{3}$ \\ ${ }^{1}$ Icelandic Meteorological Office, Bústadavegi 9, IS-150, Reykjavik, Iceland \\ ${ }^{2}$ University of Iceland and Icelandic Meteorological Office, Bústadavegi 9, IS-150, Reykjavik, Iceland \\ ${ }^{3}$ Centre d'Études de la Neige, Météo-France, 1441 rue de la Piscine, 38406 Saint-Martin-d'Hères Cedex, France
}

\begin{abstract}
SAFRAN and Crocus are simulation systems developed at the Centre d'Études de la Neige, the snow research department of Météo-France. SAFRAN analyzes weather parameters relevant to snow on the ground, and Crocus simulates the build-up of the snowpack. In this study, simulated snow depths and measured snow depths at three locations in Iceland were compared. The main study was performed for the Hveravellir weather station located $640 \mathrm{~m}$ a.s.l. in central Iceland. The results from three winters, 1994-97, were analyzed. In Iceland the "Alpine" version of the models systematically underestimated the snow depth and density of the snowpack. Corrections for the effect of wind on snow density and on precipitation measurements led to significant improvements in simulated snow depths. The simulations are sensitive to the threshold temperature between snow and rain. The remaining problems in simulating the snowpack are mainly related to transport of snow by wind, which is not accounted for in the models, and to some extent to melting and sublimation in strong winds.
\end{abstract}

\section{INTRODUGTION}

Models have been developed at the Centre d'Études de la Neige, the snow research department of Météo-France, to simulate the snow cover and forecast avalanche danger, as described by Brun and others (1989), Durand and others (1998, 1999) and Giraud and others (1998). The inputs to the models are daily meteorological observations as well as an analysis and forecasts from a meteorological model. SAFRAN (Système d'Analyse Fournissant des Renseignements Atmosphériques à la Neige) estimates relevant meteorological parameters that affect snowpack evolution, such as air temperature, wind speed, precipitation, air humidity, cloudiness, longwave radiation, direct and scattered solar radiation. The results of SAFRAN are used by Crocus to simulate the physical processes inside the snowpack and its stratigraphy. The SAFRAN and Crocus (SG) models have been in operational use in the French Alps since 1992 and are also used in the Pyrenees. They have been improved using feedback from snow observers and observational data during that period.

It is important to gain better understanding of the snow cover, forecast its development and further develop the models for different circumstances. SAFRAN and Crocus are being tested and adapted to Iceland's oceanic climate and strong winds. They were previously tested in maritime climatic conditions in Canada (Mingo and McClung, 1998) and Norway (Petersen, 1998). In Canada they were tested in an area with a snow climate transitional between maritime and continental type, and also in an area with a maritime snow climate with mild temperatures and deep snowpacks. The snow cover lasted throughout the winter. The densities were underestimated in one of the locations, due to wind and gusts of wind. Good agreement was obtained between simulated and measured snow depth.
In Norway Crocus was tested at locations near the Arctic Circle, approximately $10 \mathrm{~km}$ from the outer coastline. The snow cover lasted throughout the winter, although some periods of melting occurred, and the wind speed normally did not exceed $5 \mathrm{~m} \mathrm{~s}^{-1}$. The models generally performed well, but difficulties arose during periods when temperatures were changing from below to above freezing and vice versa.

More than 10 towns in Iceland are located in areas with avalanche risk. After two major avalanche catastrophes in 1995, the Icelandic Meteorological Office became responsible for the evacuation of towns and villages during avalanche danger. Precipitation intensity and subsequent snow accumulation, as well as snow stratigraphy, have been primary parameters used for avalanche warning in Iceland. Usually the most severe danger develops during snowstorms lasting for several days. Under such conditions it is difficult to obtain information about the development of the snowpack in the field. A model to simulate the snow cover and thus help forecast avalanche danger would be a very important means of improving avalanche warnings.

\section{GLIMATE AND OBSERVATIONAL DATA}

Iceland is an island in the North Atlantic (Fig. 1) with a humid, oceanic climate. Rapid weather changes related to frequent extratropical cyclones are common. Lows are frequently in the vicinity or moving across the country. The frontal areas often bring strong winds and heavy precipitation. The weather is more unstable than in the French Alps where the models were originally developed and tested.

The main study was done for Hveravellir (Fig. 1), a manned weather station located in the central highland of Iceland. Hveravellir is relatively far from the coast, and the 


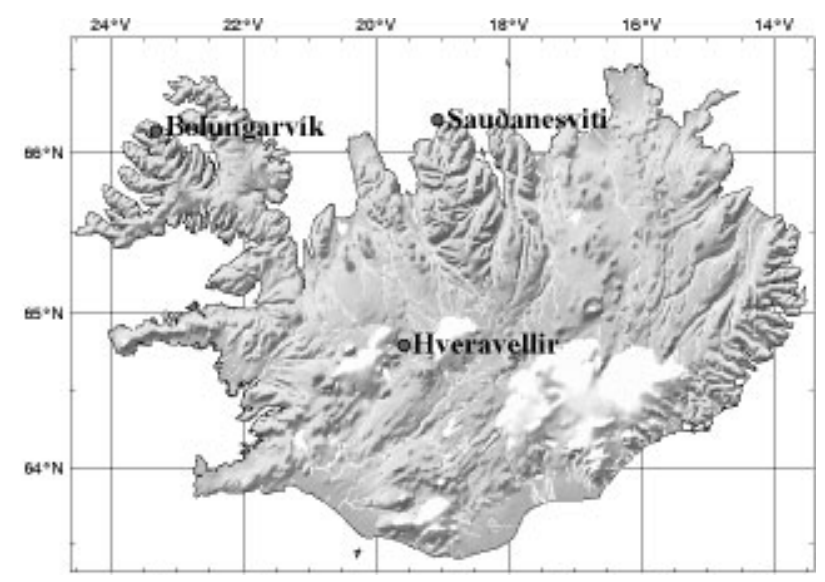

Fig. 1. Iceland, location of the three weather observation stations used in the tests.

temperature is usually below zero during winter (Table 1). The temperature conditions at Hveravellir are thus more similar to those in the operational areas in the French Alps than to those on the Icelandic coast.

The models were also tested for two manned coastal weather stations in north and northwest Iceland. The station at Sauðanesviti lies on a peninsula close to the town of Siglufjörður, and the other station is located in Bolungarvík; both towns are endangered by avalanches. The mountains above these towns are 600-700 m high.

At Sauðanesviti, synoptic weather observations are made every 3 hours except at 0300 GMT (Greenwich mean time), and at Hveravellir and Bolungarvík every 3 hours, day and night. The measured precipitation is summarized over 24 hours.

At Hveravellir, snow depth is measured at 1100 GMTat 35 permanent stakes. The average depth at all the stakes is used in this study. Due to strong winds, spatial variation of snow depth is large, but the location of the stakes is such that an average snow depth should provide a reasonably accurate estimate of the snow depth in the area. Some snow-density measurements are also available from Hveravellir.

At Sauðanesviti and Bolungarvík, the quality of daily snow observations is not as high as at Hveravellir, but still based on an average at several locations.

\section{The three winters}

All the stations have a windy climate. Winter 1994/95 was

Table 1. Test stations

\begin{tabular}{|c|c|c|c|c|c|c|c|}
\hline \multirow[t]{2}{*}{ Observation station } & Elevation & $\begin{array}{l}\text { Period } \\
\text { (1 Aug. } \\
-31 \text { July) }\end{array}$ & $\begin{array}{c}T_{\text {avg }} \\
\text { in } \\
\text { Nov. }\end{array}$ & $\begin{array}{c}T_{\text {avg }} \\
\text { in } \\
\text { Feb. }\end{array}$ & $\begin{array}{c}T_{\text {avg }} \\
\text { in } \\
\text { Apr. }\end{array}$ & $\begin{array}{l}r_{\text {year }}= \\
\text { measured } \\
\text { precipit. }\end{array}$ & $\begin{array}{c}\text { Max. snow } \\
\text { depth }\end{array}$ \\
\hline & ma.s.l & & ${ }^{\circ} \mathrm{C}$ & ${ }^{\circ} \mathrm{C}$ & ${ }^{\circ} \mathrm{C}$ & $\mathrm{mma}^{-1}$ & $\mathrm{~cm}$ \\
\hline \multirow[t]{3}{*}{ Hveravellir } & 641 & $1994 / 95$ & -3.6 & -8.9 & -4.7 & 1414 & 121 \\
\hline & & $1995 / 96$ & -3.5 & -6.5 & -1.3 & 1081 & 60 \\
\hline & & $1996 / 97$ & -8.4 & -7.1 & -1.7 & 1172 & 105 \\
\hline \multirow[t]{3}{*}{ Sauðanesviti } & 30 & $1994 / 95$ & 2.2 & -2.4 & -0.3 & 1860 & 86 \\
\hline & & $1995 / 96$ & 2.0 & -0.5 & 2.3 & 1727 & 28 \\
\hline & & 1996/97 & -1.0 & -1.5 & 2.3 & 1365 & 66 \\
\hline \multirow[t]{3}{*}{ Bolungarvík } & 23 & $1994 / 95$ & 0.7 & -3.1 & -0.8 & 744 & 63 \\
\hline & & $1995 / 96$ & 1.5 & -1.7 & 1.2 & 1295 & 30 \\
\hline & & $1996 / 97$ & -2.0 & -2.8 & 1.8 & 1381 & 78 \\
\hline
\end{tabular}

unusually severe in north and northwest Iceland. The average wind speed was $7.7 \mathrm{~m} \mathrm{~s}^{-1}$ at Sauðanesviti (maximum $29 \mathrm{~m} \mathrm{~s}^{-1}$ ) and $8.7 \mathrm{~m} \mathrm{~s}^{-1}$ at Hveravellir (maximum $41 \mathrm{~m} \mathrm{~s}^{-1}$ ). Further information about temperature, measured precipitation and maximum snow depth during the three test winters is shown in Table 1.

Winter 1995/96 had little snow overall, except in October when an avalanche cycle lasted for several days in the north and northwest. The snow accumulation during this avalanche period was, however, poorly represented at the coastal stations.

Winter 1996/97was considered average with respect to snow conditions.

\section{Snow densities}

Jóhannesson and others (1998) compared conditions in Iceland and Switzerland, and found that the density of a stable mid-winter snowpack in north Iceland is 400-450 $\mathrm{kg} \mathrm{m}^{-3}$, substantially higher than in the Swiss Alps. They also found that snow density in Iceland, unlike that in Switzerland, appears to be relatively independent of altitude. The densities measured in Iceland were similar to those measured in Grasdalen, Norway.

Measurements in fracture lines of avalanches have shown high densities as well. Two days after the Flateyri avalanche in northwest Iceland in 1995, the density in the fracture line was $360 \mathrm{~kg} \mathrm{~m}^{-3}$ (Haraldsdóttir, 1998). The snow accumulated during a storm in which measured wind speed in the mountains reached $48 \mathrm{~m} \mathrm{~s}^{-1}$ (10 min average), but the average wind speed during the 3 days prior to the avalanche was $30 \mathrm{~m} \mathrm{~s}^{-1}$. The temperature close to the starting zone was $-4^{\circ}$ to $-10^{\circ} \mathrm{C}$ during that period.

\section{TESTS OF SAFRAN AND GROGUS}

The SC models were used to simulate snowpack development at the previously described locations in Iceland during three winters. Observations from the three stations were used as input, together with analysis of relevant atmospheric parameters from the European Centre for Medium-range Weather Forecasts.

The "Alpine" version of the SC models, as described by Brun and others (1989) and Durand and others (1998, 1999), was tested with Icelandic data by comparing simulated snow depths from the models with the observed snow depth. Adjustments were made to take into account the impact of high winds on the density of the snowpack and precipitation-measurement errors. Studies of snow-depth sensitivity to the value of the threshold temperature between snow and rain were also conducted.

\section{Snow densities}

Strong wind leads to branches breaking off the snow crystals, creating small fine-grained snow, so the snow on the ground becomes more dense. The impact of temperature and wind on the density of new snow in Crocus is calculated by the equation

$$
\rho=k_{1}+k_{2}(T-273.15)+k_{3} U^{k_{4}},
$$

where $\rho$ is density, $k_{1}, k_{2}, k_{3}$ and $k_{4}$ are constants, $T$ is temperature and $U$ is the wind speed. In the sensitivity tests using the Icelandic data, $k_{3}$ was changed from 0.026 to 0.04 , and $k_{4}$ from 0.5 to 0.75 . The density therefore increased more in the new simulations with increased wind speed than it did with the original values of the constants. 


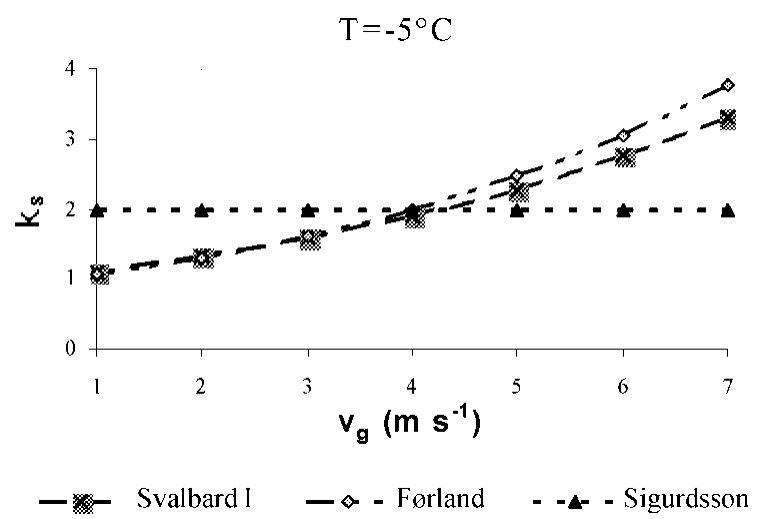

Fig. 2. Precipitation-correction factor for snow, $k_{\mathrm{s}}$, for Svalbard I,"Forland" (Forland and others, 1996; Førland and HanssenBauer, 2000) and Sigurdsson (1990). According to Svalbard I and Forland, $k_{\mathrm{s}}$ increases with decreasing temperature down to $-12^{\circ} \mathrm{C}$ and also increases with increasing wind speed up to $7 \mathrm{~ms}^{-1}$. Sigurdsson suggested a constant of 2 for Hveravellir.

\section{Precipitation corrections}

It is generally accepted that measured precipitation in wind and temperature below $0^{\circ} \mathrm{C}$ gives an underestimate of the "ground true" precipitation. The most important source of error is the wind, which directly affects the flow around the gauge, though some types of gauges have wind shields to reduce this effect. Snowdrift also affects the measurements. Wetting of the interior of the rain gauge and evaporation can also be important.

A simple precipitation-correction method employs an equation of the form

$$
P_{\mathrm{c}}=k\left(P_{\mathrm{m}}+\Delta P_{\mathrm{w}}+\Delta P_{\mathrm{E}}\right),
$$

where $P_{\mathrm{c}}$ is "ground true" precipitation, $k$ is a correction factor, $P_{\mathrm{m}}$ is measured precipitation, $\Delta P_{\mathrm{w}}$ is a correction for wetting of the rain gauge and $\Delta P_{\mathrm{E}}$ is a correction for loss from evaporation (e.g. Sigurðsson, 1990; Førland and HanssenBauer, 2000). The correction factor, $k$, is a function of temperature and wind speed at the wind-gauge level.

Three precipitation-correction methods have been studied to find the best way of estimating the precipitationcorrection factor $k$.

A Nordic study was performed at Jokioinen, southwest Finland (Førland and others, 1996; Førland and HanssenBauer, 2000), and the results were correction factors for solid $\left(k_{\mathrm{s}}\right)$ and liquid $\left(k_{\mathrm{l}}\right)$ precipitation. According to this Nordic study, the measured winter precipitation may be $<50 \%$ of the true amount in wind-exposed coastal and mountainous areas in the Nordic countries.

A further study was made in Svalbard $\left(78^{\circ} 56^{\prime} \mathrm{N}, 11^{\circ} 53^{\prime} \mathrm{E}\right)$ which reached higher wind speeds (Hanssen-Bauer and others, 1996), and the correction method Svalbard I was among the results. Here, as in the Nordic study, there were only a few occurrences of snowfall in strong wind.

Sigurðsson (1990) studied runoff and precipitation measurements in Iceland. He suggested a correction factor of 2 for solid precipitation or snow for Hveravellir as an average for a year, and 1.32 for liquid precipitation or rain.

The correction factor for solid precipitation for the Svalbard I and Førland methods is a function of temperature, $T_{\mathrm{g}}$, and wind speed, $v_{\mathrm{g}}$, at the height of the rain gauge.

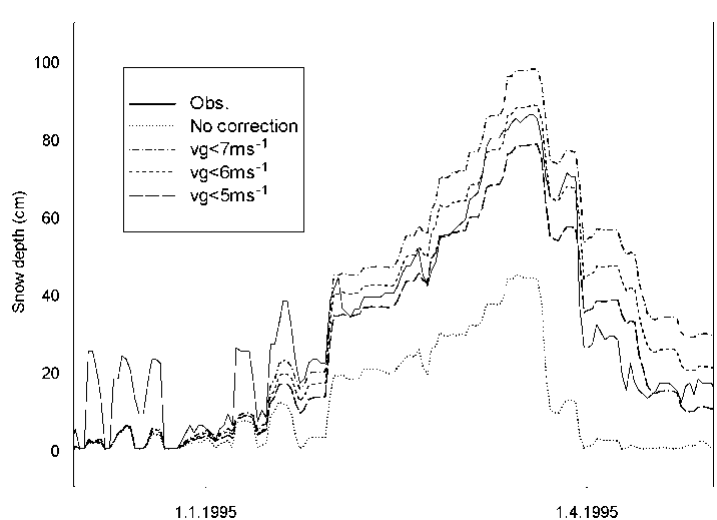

Fig. 3. Observed snow depth, simulated snow depth without correction (original model) and examples of simulated snow depth with precipitation correction for various limits of the critical wind speed and the Icelandic density formulation at Saudanesviti, 1994/95.

For liquid precipitation it was a function of the wind speed and the precipitation intensity. The limits set for the formulation of the precipitation-correction factor were the ones reached at the test site in Finland during the measurements $T \geq-12^{\circ} \mathrm{C}$ and $v_{\mathrm{g}} \leq 7 \mathrm{~m} \mathrm{~s}^{-1}$.

Figure 2 shows the three precipitation-correction models. They are plotted against wind speed, at $T=-5^{\circ} \mathrm{C}$. The figure also shows the correction factor of 2 suggested by Sigurdsson. Similarly, average long-term values of 1.15 (liquid precipitation) and 1.85 (solid precipitation) have been suggested for Svalbard by Førland and Hanssen-Bauer (2000).

For low wind speeds the Svalbard I and Førland curves are almost identical, while for wind speeds greater than about $4 \mathrm{~m} \mathrm{~s}^{-1}$ Svalbard I gives lower values of the correction factor. For values close to $7 \mathrm{~m} \mathrm{~s}^{-1}$, both models give a correction factor of 3-4 and even greater for lower temperatures. With average wind speeds of $>8 \mathrm{~m} \mathrm{~s}^{-1}$, both the Svalbard I and Førland models would give precipitation amounts in Hveravellir that are far beyond the Sigurðsson model. Bearing in mind that the correction curves in the Svalbard I and especially in the Førland model are based on only a limited number of observations at high wind speeds and that Sigurðsson's study relates the measured precipitation to the actual runoff in the Hveravellir area, the present study employs a correction factor based on the Svalbard I model for wind speed at gauge level $v_{\mathrm{g}}$, but only up to a critical wind speed. For greater wind speeds the correction factor has the same value as for the critical wind speed. Some sensitivity tests of the value of the wind-speed limit were conducted (Fig. 3). They are discussed later in this paper.

Estimation of the wind at the height of the rain gauge is based on observations at $10 \mathrm{~m}$ height and a local study of the average vertical profile of wind speed (Arason, 1998) stating that

$$
V_{2} V_{1}=\left(H_{2} / H_{1}\right)^{0.16},
$$

where $V_{2}$ is the speed at height $H_{2}$ and $V_{1}$ is the speed at height $H_{1}$.

This gives a wind speed at gauge level $\left(v_{\mathrm{g}}\right)$, which is $1.5 \mathrm{~m}$ above the ground, of $74 \%$ of the wind speed at $10 \mathrm{~m}$ height.

\section{The threshold temperature, $T_{\mathrm{c}}$}

A study of synoptic weather observations (Ólafsson and Haraldsdóttir, 2000) over a period of 30 years showed that 


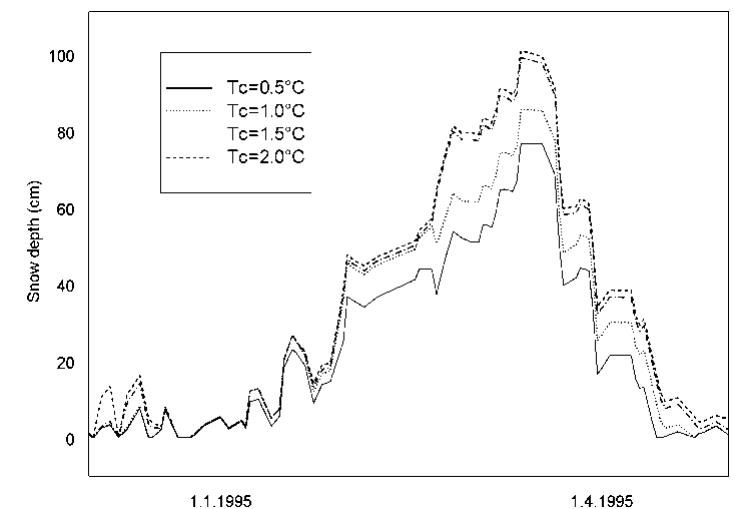

Fig. 4. Simulated snow depth for various threshold temperatures between snow and rain, $T_{\mathrm{c}}$, and the Alpine density formulation at Sauðanesviti 1994/95. The simulations included a precipitation correction.

the threshold temperature between snow and rain $\left(T_{\mathrm{c}}\right)$ has large spatial variation in Iceland, ranging from about $0.5^{\circ}$ to $2^{\circ} \mathrm{C}$. This large variability is due to differences in the proportion of stratiform and convective precipitation and variations of the static stability of the low-level air masses, which is largely influenced by the proximity of a warm ocean and mountains. $T_{\mathrm{c}}$ was estimated to be $1.0^{\circ} \mathrm{C}$ at Hveravellir and Sauðanesviti, as in the original models for the Alps, but $1.5^{\circ} \mathrm{C}$ at Bolungarvík.

\section{RESULTS}

Figure 4 shows the effect of the threshold temperature on snow-depth simulations. The maximum difference in the simulations in the figure is $29 \mathrm{~cm}$, or $34 \%$ of the maximum observed snow depth. The temperature at the coastal stations is close to $0^{\circ} \mathrm{C}$ more often than at Heravellir, so they are more sensitive to the value of $T_{\mathrm{c}}$.

Table 2 shows observed and simulated densities of the snowpack at Hveravellir. The observed density is formulated with the "Alpine" values of $k_{3}$ and $k_{4}$, while simulated density uses the "Icelandic" values of $k_{3}=0.04$ and $k_{4}=0.75$. The models greatly understimate the density, and a considerable improvement is achieved by increasing the wind effects on density. The density on 1 November 1994 is, however, overestimated by the models, mainly because the snow pits do not correctly represent the snowpack.

In Table 2, the average difference between observed and

Table 2. Observed and simulated densities, from the original (Alpine) version of Crocus and from the "Icelandic" Crocus (using $k_{3}=0.04$ and $k_{4}=0.75$ in Equation (1)).Precipitation correction is employed

\begin{tabular}{lccccc}
\hline Date & $\begin{array}{c}\text { Obs. } \\
\text { average } \\
\text { density }\end{array}$ & $\begin{array}{c}\text { Alpine } \\
\text { Crocus } \\
\text { density }\end{array}$ & $\begin{array}{c}\text { Alpine } \\
\text { Crocus } \\
\text { /Obs. }\end{array}$ & $\begin{array}{c}\text { Icelandic } \\
\text { Crocus } \\
\text { density }\end{array}$ & $\begin{array}{c}\text { Icelandic } \\
\text { Crocus } \\
\text { /Obs. }\end{array}$ \\
& $\mathrm{kg} \mathrm{m}^{-3}$ & $\mathrm{~kg} \mathrm{~m}^{-3}$ & & $\mathrm{~kg} \mathrm{~m}^{-3}$ & \\
\hline 1 Nov. 1994 & 140 & 168 & 1.20 & 198 & 1.41 \\
20 Jan 1995 & 342 & 294 & 0.86 & 383 & 1.12 \\
20 Feb. 1995 & 425 & 298 & 0.70 & 369 & 0.87 \\
21 Mar. 1995 & 432 & 292 & 0.68 & 365 & 0.84 \\
21 Apr. 1995 & 443 & 402 & 0.91 & 460 & 1.04 \\
\hline
\end{tabular}

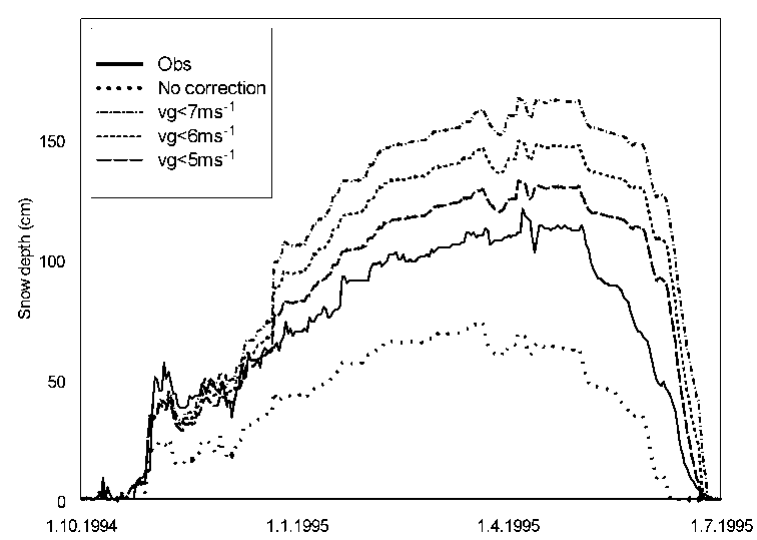

Fig. 5. Observed snow depth, simulated snow depth without correction (original model) and simulated snow depth with the Icelandic density formulation and precipitation correction for various critical wind-speed limits at Hveravellir, 1994/95.

simulated density is $21 \%$ for the Alpine version, while after the density corrections (Icelandic density) the difference is $17 \%$. If only the period of thick snowpack is considered, i.e. excluding 1 November 1994, the corresponding differences are $22 \%$ and $11 \%$, which is indeed a good improvement.

The precipitation corrections proved to be important for the windy climate. After setting the threshold temperature between snow and rain, as explained in the previous section, and including the above density correction, the precipitation was corrected. The simulated snow depth is very sensitive to the precipitation correction, as can be seen in Figure 3 (Sauðanesviti 1994-95) which shows the Svalbard I model applied up to different critical wind speeds. The bottom curve is the original model, but all the other curves include both density correction and precipitation correction. Critical wind speed of $5 \mathrm{~m} \mathrm{~s}^{-1}$ gave the best overall results when comparing observed and simulated snow depths.

Figure 5 is from Hveravellir, 1994-95, and shows that the simulated snow depths using precipitation correction with critical wind speed at $7 \mathrm{~m} \mathrm{~s}^{-1}$ are high compared with the observed snow depth. Most of the simulations are good except for 22 December, when a mixture of rain and snow was simulated only as snow in the models. The increase in snow depth was $2 \mathrm{~cm}$ in the observations but $15 \mathrm{~cm}$ in the models, a difference that continued throughout the snow season. Figure

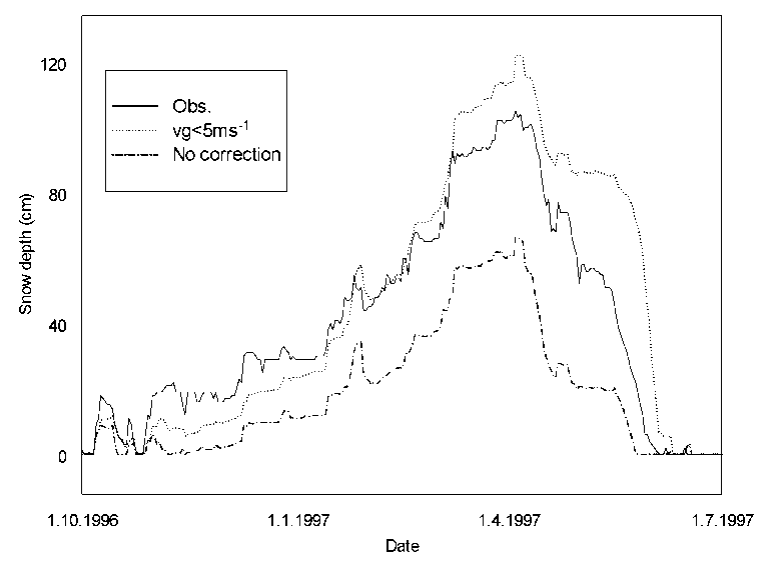

Fig. 6. A result of the model adaptation for Hveravellir, 1996/97: observed snow depth, simulated snow depth with precipitation correction with a critical wind-speed limit of $5 \mathrm{~m} \mathrm{~s}^{-1}$ and the Icelandic density formulation, and simulated snow depth without correction (original model). 


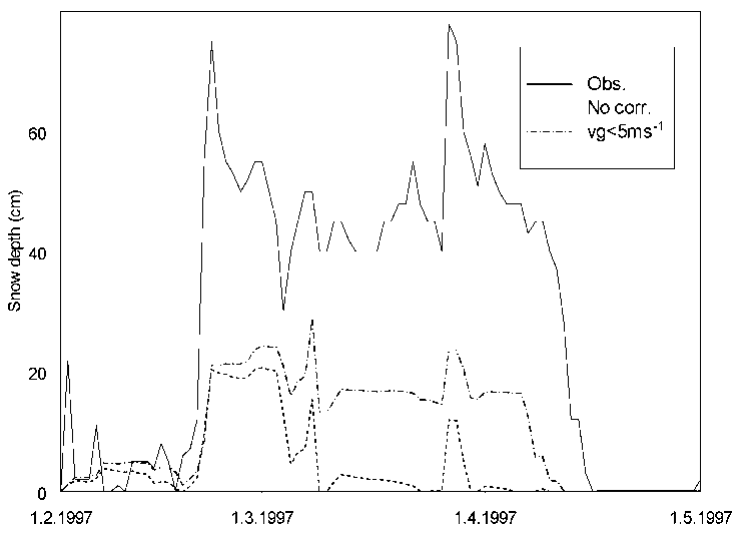

Fig. 7. A result of the model adaptation for Bolungarvik 1996/97: observed snow depth, simulated snow depth without correction and simulated snow depth with the Icelandic density formulation and precipitation correction with a critical wind-speed limit of $5 \mathrm{~m} \mathrm{~s}^{-1}$.

6 shows the observed and simulated snow depth during the entire winter season 1996/97 at Hveravellir. The importance of the precipitation correction is evident, but so is an underestimation by the models of the melting of the snowpack in the spring.

Figure 7 shows the snow depth at Bolungarvík in spring 1997. The simulations do not reproduce the two snow-depth maxima. A close study of the associated weather revealed
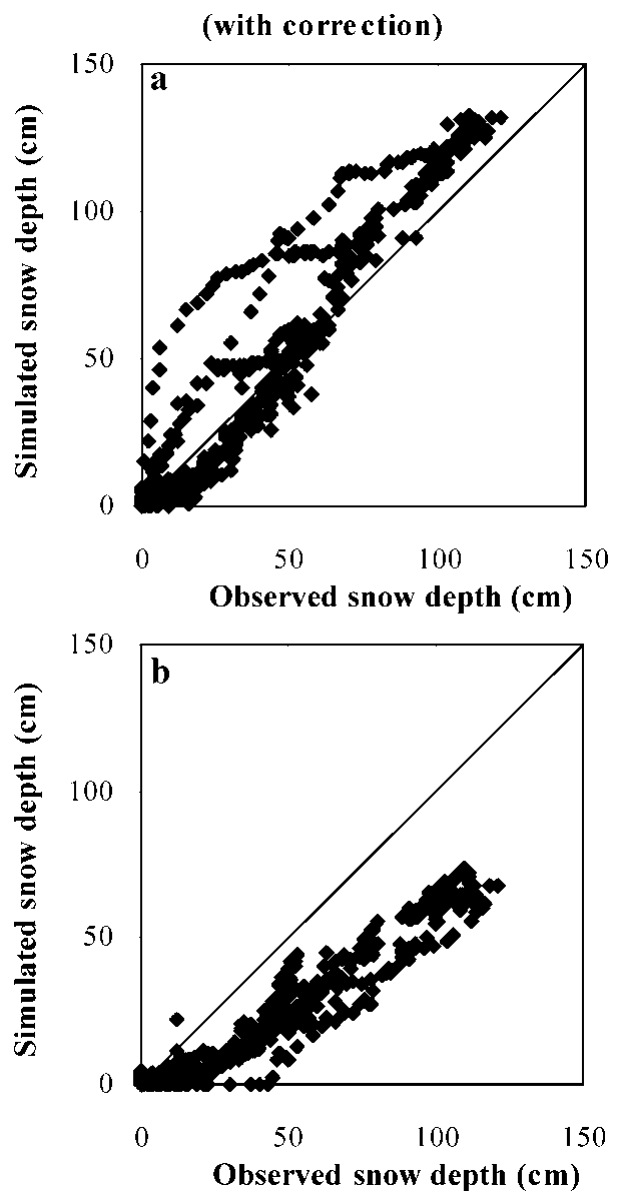

Fig. 8. Results of the adaptation of the models at Hveravellir, 1994-97: simulated snow depth vs observed snow depth. (a) The Icelandic density formulation and precipitation correction with a critical wind-speed limit of $5 \mathrm{~ms}^{-1}$. (b) Original (Alpine) model. that wind directions were particularly favourable for snow transport and accumulation at the observation site. The accumulation appears to be poorly represented in precipitation measurements and consequently also in the simulations.

The overall results of the simulations of snow depth before and after density and precipitation corrections at Hveravellir, Sauðanesviti and Bolungarvík are shown in Figures $8-10$. The improvement due to the corrections is considerable at Hveravellir and Sauðanesviti. Bolungarvík is the hardest one to simulate. The largest remaining errors are related to wrong melting and sublimation in the models and snowdrift.

\section{DISGUSSION}

There is a satisfying overall agreement between observed and simulated snow depth at Hveravellir and Sauðanesviti after changing the formulation for the density of new snow and correcting the precipitation. Apart from melting and sublimation in strong winds and snowdrift, the inaccuracy of the snow observations becomes a factor limiting further development of the models for operational use in Iceland. In some cases, such as at in Bolungarvík in spring 1997, it is reasonable to believe that the models give a better picture of the average snow depth over a large area than do the observations, since they do not simulate the effects of snowdrift.

The models generally performed better at Hveravellir than at the two coastal stations. The coastal regions are char-
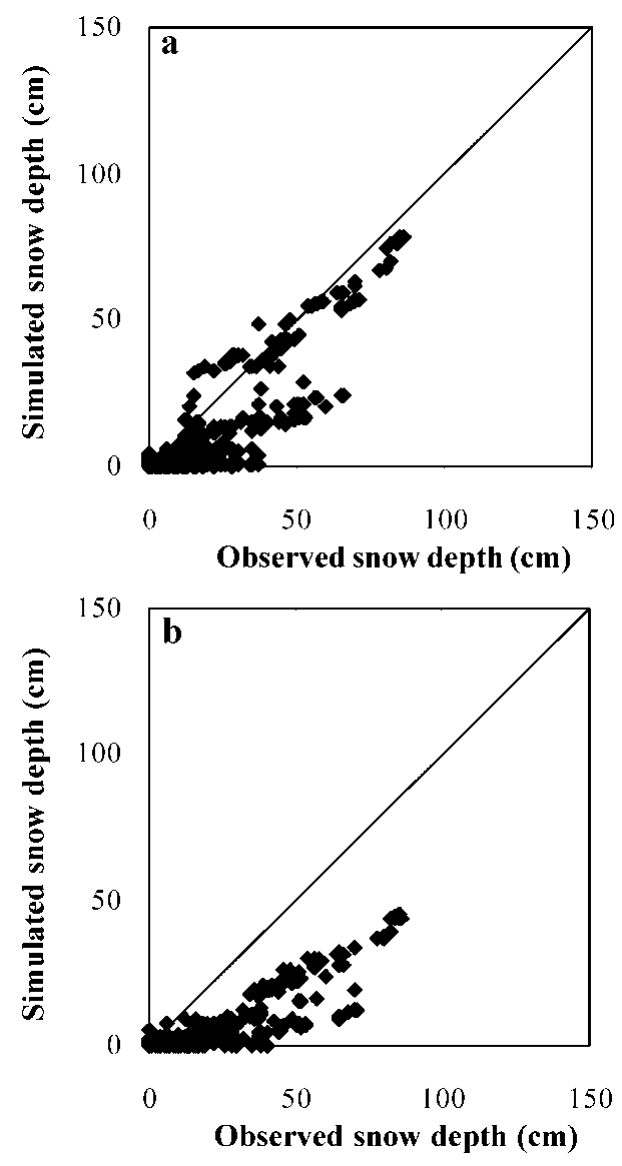

Fig. 9. Results of the adaptation of the models at Saudanesviti, 1994-97: simulated snow depth vs observed snow depth. (a) The Icelandic density formulation and precipitation correction with a critical wind-speed limit of $5 \mathrm{~ms}^{-1}$. (b) Original (Alpine) model. 

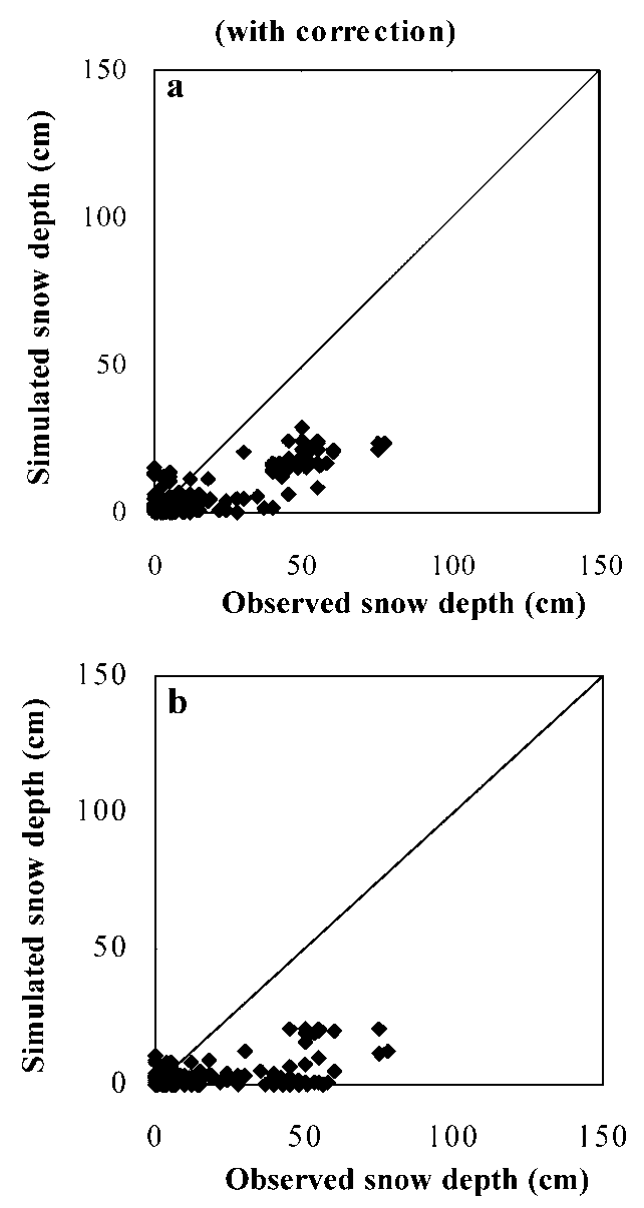

Fig. 10. Results of the adaptation of the models at Bolungarvik, 1995-97: simulated snow depth vs observed snow depth. (a) The Icelandic density formulation and precipitation correction with a critical wind-speed limit of $5 \mathrm{~m} \mathrm{~s}^{-1}$. (b) Original (Alpine) model.

acterized by periods of strong and warm winds that lead to melting and sublimation which is not well represented by the models, as seen at Sauðanesviti in late March 1995 (Fig. 3).

Rapid temperature changes associated with heavy precipitation are another characteristic of the climate in Iceland. In some cases when the temperature is passing the threshold value of temperature for solid/liquid precipitation, the models show relatively large errors. This feature was more obvious at the coastal stations with the rapidly changing temperatures around $0^{\circ} \mathrm{C}$ than at Hveravellir, where temperatures are $<0^{\circ} \mathrm{C}$ for most of the winter. Solving such problems requires continuous measurements of precipitation and temperature, which hopefully will be available soon.

The models do not take into account snowdrift, or transport of snow by wind. In a climate where strong winds are frequent this leads to errors. Taking the average of observed snow depth at many stakes reduces these errors. Further modelling efforts are being made for snowdrift (Durand and others, 2001). Although a simple model for correcting drifting snow is being developed, simulating the snowdrift in a complex terrain remains a major challenge.

\section{GENERAL CONGLUSIONS AND FUTURE WORK}

Initial results are promising for the possible use of the models in Iceland. The results improved by adjusting to the unstable, windy climate which is quite different from that in the Alps.
Applying a correction for precipitation measured in strong wind made the most important improvement, together with corrections for wind effect on new-snow density. Other wind effects, such as melting and sublimation during periods of strong wind and snow transport, still remain to be simulated.

In the future, information from snow pits in avalanche towns in the neighbourhood of the weather stations will be compared with the simulation of the snowpack structure, such as densities, and crystal morphology. This should lead to further improvement of the models.

The models have now been set up to be tested in daily operation for avalanche warning, using the forecast of increase in snow depth as a warning sign at the first stage. Applying the results of the present study will lead to significant improvement of the models in this context.

\section{ACKNOWLEDGEMENTS}

The cooperation between workers from France and Iceland is promising for the future development of the SC models for the Icelandic climate. C. Fierz and M. M. Magnússon gave valuable advice and made helpful comments on the paper, and $\mathrm{E}$. Førland advised on the section on precipitation correction. An anonymous reviewer also made many useful suggestions and comments. L. Tracy helped with the language.

\section{REFERENGES}

Arason, p. 1998. Mat á vindi á fyrirhugðum brúm í Reykjavik. Reykjavík, Veðurstofa Islands. (VI-G98017-TA01.)

Brun, E., E. Martin, V. Simon, C. Gendre and C. Coléou. 1989. An energy and mass model of snow cover suitable for operational avalanche forecasting. F. Glaciol., 35(121), 333-342.

Durand, Y., G. Giraud and L. Mérindol. 1998. Short-term numerical avalanche forecast used operationally at Météo-France over the Alps and Pyrenees. Ann. Glaciol., 26, 357-366.

Durand, Y., G. Giraud, E. Brun, L. Mérindol and E. Martin. 1999. A computerbased system simulating snowpack structures as a tool for regional avalanche forecast. F. Glaciol., 45(151), 469-484.

Durand, Y., G. Guyomarc'h and L. Mérindol. 2001. Numerical experiments of wind transport over a mountainous instrumented site: Part 1. Regional scale. Ann. Glaciol., 32 (see paper in this volume).

Førland, E. J. and I. Hanssen-Bauer. 2000. Increased precipitation in the Norwegian Arctic: true or false? Climatic Change, 46(4), 485-509.

Førland, E. J. and 9 others. 1996. Manual for operational correction of Nordic precipitation data. Oslo, Det Norske Meteorologiske Institutt. (DNMI Klima Rapport 24.)

Giraud, G., E. Brun, Y. Durand and E. Martin. 1998. Safran/Crocus/Mepra models as a helping tool for avalanche forecasters. In Hestnes, E., ed. 25 Years of Snow Avalanche Research, Voss 12-16 May 1998. Proceedings. Oslo, Norwegian Geotechnical Institute, 108-112. (NGI Publication 203.)

Hanssen-Bauer, I., E. J. Førland and P. Ø. Nordli. 1996. Measured and true precipitation at Svalbard. Oslo, Norsk Meteorologisk Institutt. (DNMI Klima Rapport 31.)

Haraldsdóttir, S. H. 1998. The avalanche at Flateyri, Iceland October $26^{\text {th }}$ 1995 and the avalanche history. In Hestnes, E., ed. 25 Years of Snow Avalanche Research, Voss 12-16 May 1998. Proceedings. Oslo, Norwegian Geotechnical Institute, 122-127. (NGI Publication 203.)

Jóhannesson, T., J. O. Larsen and J. Hopf. 1998. Pilot project in Siglufjörður. Interpretation of observations from the winter 1996/97 and comparison with similar observations from other countries. Reykjavík, Veðurstofa Íslands. (VÍ-G98033ÚR26.)

Mingo, L. and D. M. McClung. 1998. Crocus test results for snowpack modeling in two snow climates with respect to avalanche forecasting. Ann. Glaciol., 26, 347-356.

Ólafsson, H. and S. H. Haraldsdóttir. 2000. Hitamörk rigningar og snjókomu. Reykjavík, Veðurstofa Íslands. (VÍ-G99013-ÚR07.)

Petersen, G. N. 1998. Meteorologiske faktorers innvirkning på snødekkets utvikling. (Cand. Scient. thesis, Universitetet i Oslo.)

Sigurðsson, F. H. 1990. Vandamál við úrkomumælingar á Íslandi. In Sigbjarnarson, G., ed.Vatnið og landið. Reykjavík, Orkustofnun, 101-110. 